\author{
prof. zw. dr hab. Janusz KALIŃSKI \\ Kolegium Ekonomiczno-Społeczne, Szkoła Główna Handlowa w Warszawie \\ e-mail: jkalins@sgh.waw.pl
}

\author{
DOI: $10.15290 /$ ose.2017.01.85.05
}

\title{
FAZY WZROSTU GOSPODARKI POLSKIEJ PO 1918 ROKU
}

\begin{abstract}
Streszczenie
Analiza wzrostu gospodarczego Polski po 1918 roku wskazuje, że zarówno w Drugiej Rzeczypospolitej, Polsce Ludowej i Trzeciej Rzeczypospolitej, mimo stosunkowo długich okresów dobrej koniunktury, nie udawało się rozwiązywać głównych problemów rozwoju. W latach międzywojennych nie przezwyciężono silnego zróżnicowania regionalnego, a wielomilionowe przeludnienie agrarne było podstawowa przyczyną ubóstwa zasadniczej części społeczeństwa. Trwający do 1978 roku wzrost gospodarczy Polski Ludowej wprawdzie rozwiązał szereg problemów odziedziczonych po Drugiej Rzeczypospolitej, ale stworzył nowe. Permanentne niedostatki artykułów konsumpcyjnych i zaniedbania w sferze infrastruktury były powodem kilkakrotnych wystapień społecznych przeciwko komunistycznej władzy. Jej upadek w 1989 roku umożliwił reformy ekonomiczne ukierunkowane w stronę gospodarki rynkowej. Poczattowo doprowadziły one do depresji transformacyjnej, aby od 1992 roku wprowadzić gospodarkę na ścieżkę wzrostu. Towarzyszące jej, rosnące zróżnicowanie społeczne uległo złagodzeniu po wejściu Polski do Unii Europejskiej, a akces podtrzymał długookresowy wzrost gospodarczy.
\end{abstract}

Słowa kluczowe: Polska 1918-2014, wzrost gospodarczy, problemy gospodarcze, problemy społeczne

\section{STAGES OF GROWTH IN POLISH ECONOMY AFTER 1918}

\section{Summary}

Analysis of Polish economic growth after 1918 indicates that both the Second Republic, the Polish People's Republic and the Third Republic, in spite of relatively long periods of good times, failed to solve the basic problems of development. In the years between the world wars, strong regional disparities were not overcome, while a multimillion agrarian overpopulation was the main reason for the poverty among a large part of society. Lasting until 1978, the economic growth of the Polish People's Republic admittedly solved a number of problems inherited from the Second Republic, but created new ones as well. Permanent shortages of consumer goods and neglect of infrastructure brought about repeated outbursts of public outrage against the communist government. Its collapse in 1989 enabled economic reforms aimed at creating a market economy. Initially, they led to transformational depression, but around 1992, the Polish economy found itself on a growth path. The accompanying social disparities have been eased following Poland's joining the European Union, which has helped sustain long-term economic growth.

Key words: Poland 1918-2014, economic growth, economic problems, social problems

JEL: N14 


\section{Wstęp}

Obserwowany od przeszło 20 lat stały wzrost gospodarczy Polski, powiązany z głębokimi przemianami strukturalnymi i społecznymi, skłania ku refleksji jego usytuowania w perspektywie historycznej. Wydaje się, że wystarczającym okresem do porównań może być niepełne stulecie od odrodzenia Rzeczypospolitej w 1918 roku. Charakteryzowały go fazy przyspieszenia, zwolnienia i zahamowania wzrostu pod wpływem różnorodnych czynników politycznych i ekonomicznych, zarówno wewnętrznych, jak i zewnętrznych. Istotne oddziaływanie miały także założenia i problemy realizacyjne w polityce gospodarczej.

\section{Druga Rzeczpospolita. Wzrost w warunkach integracji i modernizacji gospodarki}

Wbrew często pokutującym stereotypom, ziemie polskie w okresie zaborów (Królestwo Polskie, Galicja i Wielkie Księstwo Poznańskie) nie pozostawały w zastoju. Wedlug Grzegorza Wójtowicza, w latach 1790-1870 ich średnioroczny wzrost gospodarczy wyniósł 1,4\%, a w latach 1870-1913 - 2,7\%. Dynamika gospodarki przewyższała światową, która wynosiła odpowiednio: $0,8 \%$ i 2,1\%. W rezultacie gospodarka ziem Polski, podzielonej między zaborców, znalazła się w 1913 roku na 10. miejscu na świecie pod względem wytworzonego produktu [Wójtowicz, 2006, s. 151 i nast.].

Mimo to, dziedzictwo zaborów zapisało się głęboką dezintegracją gospodarki ziem polskich i silnym zróżnicowaniem regionalnym. W opinii Wójtowicza, w 1913 roku średni dochód na osobę wynosił 2569 dolarów (siła nabywcza dolara z 2004 roku). Jednak w przypadku mieszkańców Wielkopolski był o blisko 45\% wyższy, zaboru rosyjskiego o 15\% wyższy, zaś zaboru austriackiego niższy o około 35\% [Wójtowicz, 2006, s. 94]. Stąd też głównym zadaniem odrodzonego w 1918 roku państwa polskiego, obok scalenia terytorialnego, było dążenie do wyrównania poziomu gospodarczego poszczególnych dzielnic kraju.

W Drugiej Rzeczpospolitej problemy związane ze zwalczaniem inflacji markowej, a następnie skutkami wielkiego kryzysu światowego sprawiły, że wzrost gospodarczy odnotowano tylko w latach 1919-1923, 1926-1929 oraz 1936-1939, czyli w okresie nieco krótszym niż połowa analizowanego dwudziestolecia. Na tle ożywienia gospodarczego zazwyczaj miała miejsce poprawa koniunktury w gospodarce światowej, która z opóźnieniem docierała do naszego kraju. Wpływ miały także inne czynniki, w równej mierze zewnętrzne, jak i wewnętrzne. W pierwszym z wymienionych okresów na koniunkturę oddziaływały: zamówienia wojskowe obejmujące walki o granice, zaangażowanie państwa w odbudowę gospodarki oraz narastająca inflacja. Do 1923 roku w wielu gałęziach przemysłu uzyskano poziom produkcji równy lub większy niż w 1913 roku. W końcu omawianego okresu dzięki odbudowie rolnictwa pojawiły się nadwyżki płodów rolnych w stosunku do zapotrzebowania wewnętrznego [Luszniewicz, 2010, s. 154-155; Małecka, 1989, s. 76-77]. Koniunkturę przerwał kryzys poinflacyjny, który był niezamierzoną konsekwencją reform skarbowych i walutowych premiera Władysława Grabskiego. 
Dla prosperity w latach 1926-1928 szczególne znaczenie miał strajk górników angielskich w 1925 roku, który umożliwił skierowanie polskiego węgla na rynki skandynawskie oraz korzystny dla eksportu spadek kursu złotego w rezultacie tzw. drugiej inflacji. Pojawiły się także możliwości wywozu żywności na rynki Anglii i Stanów Zjednoczonych. Jednocześnie na uwagę zasługują skutki stabilizowania i porządkowania gospodarki, które zaowocowały wzrostem wydajności pracy. Istotne znaczenie miał napływ pożyczek i kapitału zagranicznego, wywołany pozytywną oceną sytuacji politycznej w Polsce po przewrocie majowym. W 1927 roku rząd uzyskał ze Stanów Zjednoczonych i Wielkiej Brytanii pożyczkę stabilizacyjną w wysokości $62 \mathrm{mln}$ dolarów i 2 mln funtów. Pożyczki zagraniczne zaciagnęły również poszczególne miasta i regiony (Warszawa, Poznań i Górny Śląsk). Bezpośrednie inwestycje zagraniczne napłynęły m.in.: z Belgii do przemysłu mineralnego i elektrotechnicznego, z Francji do bankowości, przemysłu ciężkiego i naftowego oraz z Włoch do bankowości i przemysłu chemicznego. Jednak największą rolę odgrywały koncerny: amerykańskie, angielskie i niemieckie, których udział w kapitale zagranicznym na terenie Polski sięgał 60\% [Landau, Tomaszewski, 1999, s. 160 i nast.].

Wobec słabości kapitału rodzimego państwo nie tylko popierało inwestycje zagraniczne, ale równocześnie angażowało własne środki. Dzięki przywilejom udzielanym inwestorom, szybko posuwała się budowa portu i miasta Gdyni, jak również przystąpiono do realizacji tzw. trójkąta bezpieczeństwa, zgrupowania przemysłu w widłach Wisły i Sanu. Państwo uczestniczyło w wydobyciu i przetwórstwie ropy naftowej, wspierało górnictwo węglowe oraz budowę zakładów mięsnych, elewatorów zbożowych, chłodni składowych i kamieniołomów. Istotny był rozwój i unowocześnienie przemysłu zbrojeniowego, opartego na pięciu skomercjalizowanych przedsiębiorstwach (Państwowe Wytwórnie Uzbrojenia, Państwowa Wytwórnia Prochu i Materiałów Kruszących, Państwowe Zakłady Lotnicze, Państwowe Zakłady Inżynierii i Państwowe Zakłady Umundurowania). W końcu lat dwudziestych państwo było największym inwestorem, a udział sektora publicznego w ogólnych nakładach na przemysł sięgał 67\% [Gołębiowski, 1985, s. 78 i nast.; Małecka, 1989, s. 81].

Duże zaangażowanie państwa i kapitału zagranicznego w inwestycje przemysłowe spowodowało znaczny wzrost produkcji przemysłowej i wpłynęło na zmiany w strukturze wytwórczości. W latach 1926-1929 produkcja przemysłowa zwiększyła się o 43\%, przy zdecydowanie szybszym wzroście wytwórczości środków inwestycyjnych i surowców w stosunku do dóbr konsumpcyjnych [Landau, Tomaszewski, 1971, s. 50 i nast.]. Ważnym osiagnięciem było unowocześnienie przemysłu, zwłaszcza zbrojeniowego, a zarazem uruchomienie produkcji nowych wyrobów, m.in.: samolotów, samochodów i taboru kolejowego.

Druga połowa lat dwudziestych przyniosła korzystne zmiany w rolnictwie związane z: realizacją reformy rolnej, postępem agrotechnicznym i rosnącym zapotrzebowaniem na żywność i surowce pochodzenia rolniczego. Powiększony został areał gospodarstw chłopskich, zwiększyło się zużycie nawozów sztucznych, rozwijano prace melioracyjne i wprowadzano nowe odmiany roślin. W rezultacie rosły plony i zbiory, a dostatek pasz przyczynił się do zwiększenia pogłowia zwierząt hodowlanych i produkcji zwierzęcej. Wartość produkcji rolniczej w roku gospodarczym 1927-1928 była 
o 67\% wyższa od średniej w latach 1922-1925 [Landau, Tomaszewski, 1971, s. 149 i nast.].

Dynamiczny rozwój polskiej gospodarki w drugiej połowie lat dwudziestych przerwał kryzys światowy. W Polsce był on odczuwany znacznie dłużej niż w państwach wysoko uprzemysłowionych i objął okres od końca 1929 do 1935 roku. Ponowne ożywienie naszej gospodarki miało swoje miejsce w poprawie koniunktury światowej i narastającym interwencjonizmie państwowym. W 1936 roku wzrosły światowe ceny produktów rolnych, co pozytywnie wpłynęło na rolnictwo polskie. Wzrost dochodów wsi przełożył się na większe możliwości zbytu produktów przemysłowych, zwłaszcza narzędzi rolniczych i nawozów sztucznych. Dalsze ożywienie w przemyśle powodował wzrost inwestycji państwowych i budownictwa mieszkaniowego [Landau, Tomaszewski, 1999, s. 251 i nast.].

Inwestycje państwowe były podstawa, przedstawionego w sejmie przez wicepremiera Eugeniusz Kwiatkowskiego, w połowie 1936 roku czteroletniego planu inwestycyjnego (od 1 lipca 1936 roku do 30 czerwca 1940 roku). W planie przeznaczono 1,8 mld zł środków publicznych na inwestycje: komunikacyjne, elektryfikacyjne i w gospodarce żywnościowej, które miały doprowadzić do ograniczenia bezrobocia. Oddzielne środki skierowano na inwestycje zbrojeniowe w ramach sześcioletniego planu rozbudowy sił zbrojnych, przygotowanego przez Sztab Główny Wojska Polskiego.

Inwestycje objęte planem cywilnym i wojskowym skoncentrowano w Centralnym Okręgu Przemysłowym (COP), który był rozwinięciem koncepcji tzw. trójkąta bezpieczeństwa. Centralny Okręg Przemysłowy obejmował wschodnie części województw: kieleckiego i krakowskiego oraz zachodnie lubelskiego i lwowskiego. Zaangażowanie inwestycyjne państwa wystapiło także poza COP-em. Nakłady skierowano m.in. do Państwowej Fabryki Olejów Mineralnych „Polmin” w Drohobyczu, Państwowej Wytwórni Uzbrojenia w Warszawie i Zjednoczonych Fabryk Związków Azotowych w Chorzowie i Mościcach. Ogółem, od kwietnia 1936 roku do marca 1939 roku, państwo wydatkowało 2,3 mld zł, z czego na inwestycje wojskowe ponad $780 \mathrm{mln}$ zł. O roli państwa świadczą proporcje udziału kapitału publicznego i prywatnego w procesie inwestycyjnym, które kształtowały się jak 77:23 [Gołębiowski, 1985, s. 206 i nast.]. Niski udział sektora prywatnego potwierdzał słabość kapitału rodzimego, lecz równocześnie był związany z zahamowaniem napływu bezpośrednich inwestycji zagranicznych do Polski w latach trzydziestych.

Rozbudowa przemysłu, szczególnie w ramach COP, zaowocowała wysoką dynamiką produkcji. W kolejnych latach okresu 1936-1938 przyrosty roczne wyniosły: 17\%, 23\%, i 10\%, a do połowy 1939 roku, w porównaniu z całym rokiem 1938, wzrost wyniósł 12\%. Między 1935 a 1938 rokiem produkcja przemysłowa podniosła się o 35 punktów procentowych, co uplasowało Polskę w szeregu najszybciej rozwijających się przemysłowo krajów na świecie. W stosunku do 1928 roku, poprzedzającego załamanie kryzysowe, w 1938 roku produkcja polskiego przemysłu była o ponad 19\% wyższa [Landau, Tomaszewski, 1989, s. 63].

Następstwem poprawy koniunktury w rolnictwie było zwiększenie powierzchni upraw i inwestycji, głównie w maszyny. Wzrosły prace melioracyjne i zakupy nawozów sztucznych. W rezultacie w latach 1934-1938 odnotowano wzrost plonów głównych 
zbóż, ziemniaków i buraków cukrowych. Wyższe, z wyjątkiem buraków cukrowych, były także zbiory. Systematycznie rosło pogłowie inwentarza żywego, przy niewielkim załamaniu liczby bydła rogatego i trzody chlewnej w 1938 roku. W efekcie wartość produkcji rolniczej w latach 1936-1938 wzrosła o ponad 31\%, a w stosunku do 1928 roku wzrost wyniósł 18\%[Landau, Tomaszewski, 1989, s. 288 i nast.].

Dobre wyniki polskiej gospodarki w latach ożywienia, 1919-1923, 1926-1929 i 1936-1939, nie w pełni zrekompensowały straty, jakie miały miejsce w czasie pierwszej wojny światowej i w okresie walk o granice między 1918 a 1921 rokiem. Zbigniew Landau i Jerzy Tomaszewski przyjęli, że wytwórczość przemysłowa Polski w latach 1913-1938 spadła o 5\%. Jednak, uznając, że wskaźnik nie był dostatecznie precyzyjnie obliczony, sformułowali konkluzję, $i \dot{z}$ wielkość globalna produkcji pržemysłowej w latach 1918-1939 nie ulegla w porównaniu z rokiem 1913 jakiejś zasadniczej zmianie [Landau, Tomaszewski, 1999, s. 293]. Autorzy wskazali na istotne zmiany strukturalne w przemyśle, związane $z$ jego dostosowaniem do potrzeb nowego państwa i unowocześnieniem produkcji. Zmniejszyła się wytwórczość produktów kierowanych przed 1918 roku do państw zaborczych, np. włókienniczych i węgla, a wzrosła przemysłu: elektrotechnicznego, chemicznego, zbrojeniowego, lotniczego i motoryzacyjnego. Poprawie uległa struktura przestrzenna przemysłu dzięki budowie COP i lokalizacji nowych zakładów na wschodzie kraju. W rolnictwie Drugiej Rzeczypospolitej, w porównaniu z 1913 rokiem, do 1938 roku wzrosły zbiory ziemiopłodów, w tym o $41 \%$ ziemniaków i o 7\% czterech podstawowych zbóż. Zwiększyło się również pogłowie zwierząt hodowlanych, w tym świń o 37\%, a koni o 12\% [Tomaszewski, Landau, 2005, s. 155 i nast.].

\section{Dochód narodowy w latach 1929-1938 (w mld zł, ceny stałe)}

WYKRES 1.

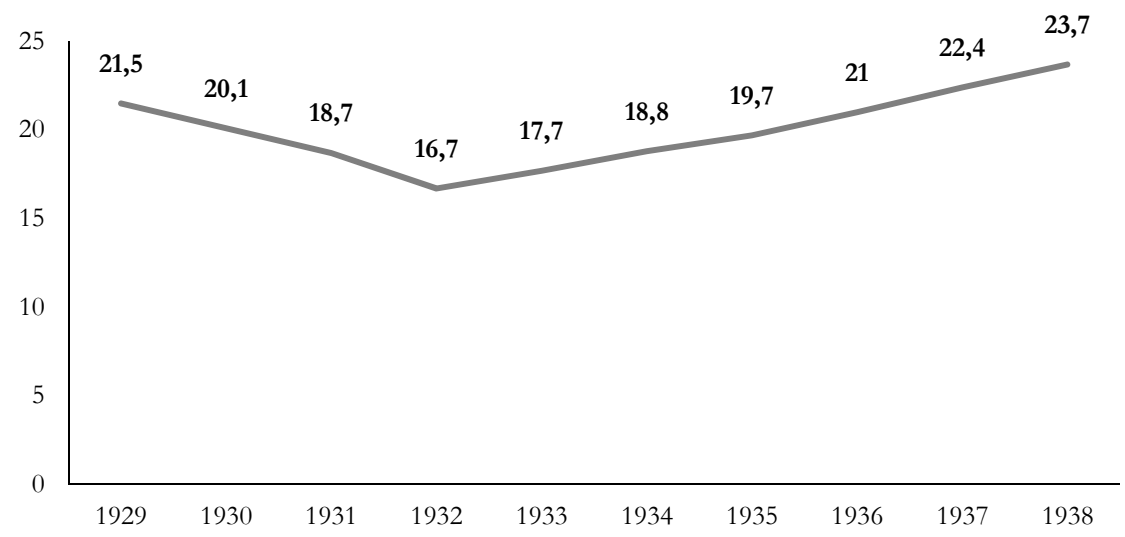

Źródło: [Historia Polski..., 2006, s. 637].

Stagnacja w produkcji przemysłowej i dobre wyniki rolnictwa polskiego różniły się od wzrostu produkcji w Europie. W rezultacie, w latach 1936-1938 wartość produkcji na jed- 
nego mieszkańca w Polsce była niższa niż przeciętnie w Europie w 1913 roku (odpowiednio: o $20 \%$ i o $24 \%$ ). Zmalał także udział ziem polskich w światowej wytwórczości rolniczej, z wyjątkiem żyta [Tomaszewski, Landau, 2005, s. 148 i 156].

Według Wójtowicza, produkt na osobę, który uległ zasadniczemu zmniejszeniu w okresie wielkiego kryzysu gospodarczego, w 1938 roku osiagnął poziom 2970 dolarów. Powrócił do poziomu z 1913 roku, przy podobnym jak przed pierwszą wojną światową znacznym zróżnicowaniu regionalnym. Udział Polski w produkcie światowym zmniejszył się z 2,13\% do 1,63\%, a w europejskim z 5,59\% do 4,65\%. Polska znalazła się o jedno miejsce niżej w rankingu światowym (z 10. na 11. miejsce), utrzymując 5. pozycję wśród gospodarek europejskich pod względem udziału w produkcji [Wójtowicz, 2006, s. 203 i 209]. Pogorszenie pozycji naszego kraju w zakresie ogólnej produkcji stanowiło koszt istotnych zmian strukturalnych związanych z odzyskaniem niepodległości i podjęciem procesu modernizacji gospodarki [Luszniewicz, 2010, s. 181].

\section{Polska Ludowa. Wzrost podporządkowany doktrynie politycznej}

Komunistyczne władze Polski trzykrotnie podejmowały politykę przyspieszonego wzrostu gospodarczego, która sprowadzała się do forsowania uprzemysłowienia. Pierwszy raz pod rządami Bolesława Bieruta, kiedy przystąpiono do realizacji planu sześcioletniego na lata 1950-1955, drugi za sprawą decyzji Władysława Gomułki z 1959 roku i trzeci po objęciu rządów przez Edwarda Gierka w 1970 roku.

Projekt planu sześcioletniego, przedstawiony w połowie lipca 1950 roku, przewidywał wzrost produkcji przemysłowej o 158\% w stosunku do 1949 roku. Jednocześnie zakładał wzmocnienie potencjału obronnego Polski w związku z poważnym zaostrzeniem się sytuacji międzynarodowej po wybuchu konfliktu koreańskiego [Minc, 1950, s. 8]. Twórcy planu, uzasadniając jego proporcje, powoływali się na „prawo socjalistycznego uprzemysłowienia”, głoszące szybszy rozwój przemysłu produkującego środki wytwórczości niż przemysłu produkującego przedmioty spożycia. Miało to gwarantować rozwój i techniczną rekonstrukcję całej gospodarki.

Ambitne i napięte zadania planu sześcioletniego zasadniczo zostały rozszerzone w drugiej połowie 1950 roku. Z pełną determinacją przystąpiono do zwiększania wytwórczości wojskowej, kosztem innych dziedzin. Militaryzacja gospodarki w istotny sposób wpłynęła na kształtowanie się struktury przemysłowej. Plany wszechstronnej industrializacji, uwzględniającej m.in. potrzeby konsumpcyjne społeczeństwa i rekonstrukcję rolnictwa, okazały się jedynie teoretyczne. Zastapił je utajniony program rozbudowy przemysłu ciężkiego i maszynowego, który dotyczył obronności oraz bazy paliwowej i surowcowej [Jaroszewicz, 1991, s. 125].

Jednostronny i ekstensywny rozwój przemysłowy, hamujący wzrost stopy życiowej ludności, w październiku 1953 roku został poddany ostrożnej krytyce przez władze. W nawiązaniu do procesów zapoczątkowanych w ZSRR po śmierci Józefa Stalina, zapowiedziano przesunięcie części środków inwestycyjnych, celem zwiększenia wytwórczości artykułów żywnościowych i przemysłowych dóbr powszechnego użytku. 
Program „przegrupowania sił i środków” był wątpliwą próba łączenia kanonów forsownej industrializacji z poprawą warunków bytowych ludności, niezbędną wobec narastającego niezadowolenia społecznego [Kuziński, 1954, s. 50].

W ostatnim roku planu sześcioletniego produkcja przemysłu uspołecznionego osiagnęła poziom o 185\% wyższy od stanu w 1949 roku. Przyrost wytwórczości środków produkcji wyniósł 196\%, zaś przedmiotów konsumpcji 171\% [Kaliński, 1987, s. 94]. O strukturze produkcji w znacznym stopniu zadecydowała dynamika produkcji przemysłu zbrojeniowego, który w zasadzie był budowany od podstaw. Militaryzacja gospodarki wyznaczyła specyfikę procesu industrializacji w powojennej Polsce. Na dalszym planie znalazły się potrzeby konsumpcyjne społeczeństwa i rozwój cywilnych gałęzi gospodarki narodowej. Niskie płace i złe zaopatrzenie w przemysłowe artykuły konsumpcyjne i żywność stały się głównymi motywami robotniczego buntu w Poznaniu, w czerwcu 1956 roku.

Rezultatem planu sześcioletniego było rozbudowanie podstaw przemysłowych gospodarki narodowej, które obejmowały tradycyjne gałęzie przemysłu ciężkiego i chemicznego. Symbolem planu sześcioletniego był kombinat metalurgiczny w Nowej Hucie, a także zakłady chemiczne w Oświęcimiu, elektrownia w Jaworznie czy Fabryka Samochodów Osobowych w Warszawie. Struktura przemysłu, po części wynikająca z przesłanek doktrynalnych, po części zaś ukształtowana pod wpływem „zimnej wojny”, tylko w ograniczonym zakresie odpowiadała warunkom kraju i potrzebom społecznym. Ewidentnie naśladowała radziecki model industrializacji z lat trzydziestych. W latach pięćdziesiątych nie było to współmierne z podstawowymi tendencjami światowymi oraz strategiami państw wysoko rozwiniętych, coraz szerzej wykorzystujących osiągnięcia rewolucji naukowo-technicznej.

W latach 1956-1958, pod wpływem powierzchownych zmian politycznych wywołanych presją społeczna, przejściowo odstąpiono od forsownego uprzemysłowienia kraju. Początkowo w polityce gospodarczej Władysława Gomułki szczególnie akcentowano wzrost stopy życiowej ludności i poprawę proporcji ekonomicznych, zdeformowanych w okresie forsownej industrializacji. Jednak już na początku 1958 roku nastąił radykalny odwrót związany ze strategia ponownego przyspieszenia wzrostu przemysłowego [Szyr, 1959, s. 15].

Ponowny wysiłek na rzecz przyszłości władze partyjne uzasadniały koniecznością zmniejszenia dystansu dzielącego Polskę od rozwiniętych państw kapitalistycznych i ściślejszego połączenia się z gospodarka bloku radzieckiego. Świadomie nasilano tendencje do samowystarczalności i tworzenia uniwersalnej struktury gospodarczej, dla której było niezbędne rozwinięcie wytwórczości przemysłu surowców i paliw. Po 1958 roku miał miejsce rozwój Rybnickiego Okręgu Węglowego, a w rejonie Turoszowa, Konina i Turka powstały kopalnie odkrywkowe węgla brunatnego, dostarczające paliwo wznoszonym tam elektrowniom. Przystapiono do budowy: ropociągu z ZSRR i zakładów rafineryjno-petrochemicznych w Płocku, huty aluminium w Koninie oraz kombinatów wydobycia i przetwórstwa złóż rudy miedzi w okolicach Głogowa oraz złóż siarki w okolicach Tarnobrzega [Lijewski, 1978, s. 15 i nast.].

W 1964 roku władze kraju przedłużyły politykę nowego etapu uprzemysłowienia o okres trzeciego planu pięcioletniego 1966-1970 [IV Zjazd..., 1964, s. 125 i nast.]. Dopiero 
pod koniec tego okresu pojawiły się tendencje do większej koncentracji uwagi na przemyśle przetwórczym i unowocześnienia jego produkcji pod hasłem selektywnego rozwoju. Chodziło o stworzenie warunków rozwoju nowoczesnych gałęzi produkcji i pogłębienie specjalizacji z myślą o zwiększeniu eksportu przemysłowego. W konsekwencji w całym okresie najwyższe nakłady przeznaczono na użytek przemysłu paliwowego i chemicznego, ale także elektromaszynowego [Kaliński, 1993, s. 114-115].

Rozpoczęty w 1959 roku drugi etap uprzemysłowienia do 1970 roku przyniósł przyrost produkcji w granicach 125\%, przy czym od 1968 roku jej dynamika zaczęła maleć. W asortymencie wytwórczości nastapił dalszy wzrost udziału: dóbr inwestycyjnych, surowców i paliw, a także branż zaawansowanej technologii (elektronika, maszyny cyfrowe). Udział przedmiotów spożycia w ogólnej wytwórczości przemysłowej zmniejszył się z 40,6\% w 1960 roku do 33,7\% w 1970 roku, dotyczyło to m.in.: wyrobów przemysłu spożywczego, skórzano-obuwniczego włókienniczego. Na niskim poziomie kształtowała się nowoczesność i jakość wyrobów konsumpcyjnych [Rocznik Statystyczny..., 1971, s. 172-173].

W rolnictwie lata 1959-1970 charakteryzowały się silnymi wahaniami wielkości produkcji, wywołanymi przez zmienne warunki atmosferyczne. Przeciętny średnioroczny przyrost wytwórczości rolnej w omawianych latach wyniósł zaledwie 2,3\% [Kaliński, 1995, s. 116 i 142]. Wyniki rolnictwa nie tylko negatywnie rzutowały na zaopatrzenie rynku w żywność, ale również niektórych gałęzi przemysłu w surowce do produkcji. Konieczne stało się ograniczenie eksportu rolno-spożywczego, który był niezmiernie istotny w bilansie handlowym z krajami kapitalistycznymi

Sytuacja w przemyśle konsumpcyjnym, w powiązaniu z trudnościami w rolnictwie i handlu zagranicznym, przyczyniała się do stagnacji stopy życiowej społeczeństwa, głównego powodu ekonomicznego kryzysu społeczno-politycznego w grudniu 1970 roku. Wydarzenia na wybrzeżu, które przyniosły dziesiątki ofiar śmiertelnych i wstrząsnęły społeczeństwem, były przesłanką zmian personalnych w komunistycznym kierownictwie kraju. Po czternastu latach rządów, od władzy został odsunięty Gomułka, a funkcję I Sekretarza KC PZPR objął Edward Gierek. Po spektakularnych działaniach na rzecz szybkiego wzrostu płac realnych, ekipa Gierka przystapiła do realizacji, nigdy niezdefiniowanej i podlegającej ciagłym zmianom, strategii „dynamicznego i harmonijnego" wzrostu. Rdzeniem tej strategii było ponowne przyspieszenie procesu industrializacji.

Nowy program gospodarczy głosił zapewnienie w pięcioleciu 1971-1975 wysokiej dynamiki rozwoju gospodarki narodowej i odczuwalnej poprawy warunków życia ludności. Tradycyjnym źródłem finansowania programu inwestycyjnego była rosnąca akumulacja wewnętrzna i, lansowane od 1971 roku, kredyty z krajów kapitalistycznych [Jędrychowski, 1982, s. 30].

W latach 1971-1975 nakłady inwestycyjne na przemysł rosły średniorocznie aż o 21\% [Bartosik, 1988, s. 183]. Przede wszystkim skierowano je do przemysłu: elektromaszynowego, paliwowo-energetycznego, metalurgicznego i chemicznego. Pewnym novum było większe, niż w latach ubiegłych, zasilenie przemysłu spożywczego, którego produkcja w dużym stopniu stanowiła o poziomie zaopatrzeniu rynku. Budowano dalsze 
kopalnie w Górnośląskim Okręgu Węglowym, Rybnickim Okręgu Węglowym i w okolicach Konina, ale także przystapiono do tworzenia dwóch nowych zagłębi - węgla brunatnego koło Bełchatowa i węgla kamiennego w pobliżu Lublina. Inwestowano w wielkie elektrownie cieplne i podjęto budowę Rafinerii Nafty w Gdańsku. W 1972 roku przystapiono do realizacji wielkiego projektu Huta Katowice, zlokalizowanego na terenie Zagłębia Dąbrowskiego. Dużym nakładem środków dokonano rekonstrukcji i rozbudowy istniejącej wytwórni w Bielsku-Białej, która wraz z nowym zakładem w Tychach utworzyła Fabrykę Samochodów Małolitrażowych [Lijewski, s. 20-22; Polska..., 1981, s. 29].

Rozmach inwestycyjny, w znacznym stopniu związany z kredytami zagranicznymi i zakupem licencji, wzrost zatrudnienia oraz wydatna poprawa w zakresie zaopatrzenia surowcowego i materiałowego zadecydowały o wysokiej dynamice produkcji przemysłowej. Jej średnioroczne tempo w pięcioleciu 1971-1975 osiagnęło 10,5\%, podczas gdy w latach 1966-1970 wyniosło 8,4\% [Rocznik Statystyczny..., 1976, s. 147].

Narastające w procesie przyspieszonego wzrost przemysłowego napięcia rynkowe, wywołane szybkim wzrostem dochodów w stosunku do podaży dóbr konsumpcyjnych, doprowadziły w Polsce Ludowej do kolejnych wystapień społecznych w czerwcu 1976 roku. Wydarzenia czerwcowe, a przede wszystkim niemożność dalszego ukrywania trudności gospodarczych, skłoniły władze do skorygowania polityki ekonomicznej. Gierek wysuną koncepcję dokonania „manewru gospodarczego” sprowadzajacego się do zwolnienia tempa wzrostu, przy preferowaniu: produkcji artykułów kierowanych na rynek i eksport, budownictwa mieszkaniowego, energetyki i transportu [Bożyk, 1983, s. 112].

Skutkiem „manewru gospodarczego" w przemyśle były spadające nakłady i powszechne zamrażanie rozpoczętych inwestycji. W rezultacie systematycznie obniżała się dynamika produkcji globalnej przemysłu, osiagając w latach 1976-1980 średnioroczny wskaźnik 4,6\%. W 1980 roku, pierwszy raz w dziejach gospodarczych Polski powojennej, nastąpił spadek produkcji przemysłowej o 0,2\% [Rocznik Statystyczny..., 1983, s. 187]. Jednak między 1971 a 1980 roku globalna produkcja przemysłowa wzrosła o 106,3\%, przy niewielkiej przewadze środków wytwarzania (106,5\%). Dość wysoki był przyrost produkcji nowoczesnych wyrobów, tj.: urządzeń do automatycznej regulacji i sterowania, obrabiarek ze sterowaniem numerycznym, lokomotyw elektrycznych, sprzętu lotniczego, systemów komputerowych i elementów półprzewodnikowych, a także samochodów osobowych, magnetofonów, pralek automatycznych i chłodziarek. Do znaczących osiagnięć należy zaliczyć podjęcie licencyjnej produkcji samochodu małolitrażowego „Fiat 126P” i odbiorników telewizji kolorowej [Polska, 1981, s. 55-56].

Przykłady te świadczyły o przyspieszeniu wytwórczości produktów powszechnie zaliczanych do nowoczesnych. Jednak nadal wysoki był udział branż tradycyjnych, wysoce materiałochłonnych, produkowanych $\mathrm{w}$ ramach specjalizacji narzuconej polskiemu przemysłowi przez Radę Wzajemnej Pomocy Gospodarczej. Na liście blisko 60 produktów, w których eksporcie specjalizowała się Polska pod koniec lata siedemdziesiątych, początkowych 10 pozycji zajmowały: węgiel kamienny, obiekty budowlane, odzież, statki morskie, podwozia samochodowe i przyczepy, wyroby walcowane, farmaceutyki, 
produkty naftowe, miedź i wyroby dziewiarskie [Błahut, 1984, s. 23 i nast.]. Dokumentowały one tradycyjną strukturę wywozu, charakterystyczną dla kraju słabo gospodarczo zaawansowanego.

Pewna liberalizacja polityki agrarnej, wyrażająca się zniesieniem tzw. obowiązkowych dostaw płodów rolnych i ułatwieniami w nabyciu ziemi przez gospodarstwa chłopskie, oraz wzrost dostaw środków do produkcji rolnej, głównie celem faworyzowania gospodarstw uspołecznionych, zaowocowały szybkim, kilkuletnim wzrostem wytwórczości. Globalna produkcja rolna w pierwszej połowie lat siedemdziesiątych wzrosła aż o19,8\%. Jednak w latach 1976-1980 pod wpływem: ograniczeń w dostawie środków do produkcji rolnej, niekorzystnej polityki cenowej państwa i zjawiska starzenia się wsi odnotowano wzrost tylko o 2,7\% [Kaliński, 1995, s. 165 i 188].

Trzykrotnie podejmowane przez władze komunistyczne wysiłki na rzecz uprzemysłowienia kraju przyniosły ponad trzydziestoletni okres wzrostu gospodarczego i imponujący statystycznie, blisko siedmiokrotny, wzrost dochodu narodowego. [Podstawowe..., 1991, s. 4-5]. Mimo to, za każdym razem kończyły się one pogorszeniem sytuacji gospodarczej kraju, a przede wszystkim położenia materialnego ludności. Industrializacja podporządkowana doktrynie politycznej doprowadziła do stworzenia anachronicznej struktury gospodarczej, odbiegającej od reprezentowanej przez państwa rozwinięte. Nastąpiło zaniedbanie takich dziedzin, jak: rolnictwo, transport i usługi, co stanowiło podstawę niskiej ekonomicznej i społecznej efektywności gospodarowania. Według rachunku Wójtowicza, produkt na osobę w latach 1950-1978 podniósł się z 3330 dol. do 8310 dol., co świadczyło o bezwzględnym zwiększeniu PKB w latach wzrostu gospodarki socjalistycznej. Dane porównawcze wskazuja, że wzrost w tempie 3,3\% rocznie był niższy niż w Europie Zachodniej (3,7\% rocznie). Spowodowało to, że poziom PKB Polski w stosunku do średniego zachodnioeuropejskiego zmniejszył się z 54\% w 1950 roku do 48\% w 1978 roku. Obniżył się także udział naszego kraju w globalnym PKB z 1,13\% w 1950 roku do 1,12\% w 1978 roku, lecz wobec perturbacji, jakie wystapiły w gospodarce świata kapitalistycznego w okresie kryzysu naftowego, Polska awansowała z 17. na 16. miejsce [Wójtowicz, 2006, s. 206, 209, 211].

WYKRES 2.

Dynamika dochodu narodowego wytworzonego w latach 1947-1989 (ceny stałe, 1950 rok $=100$ )

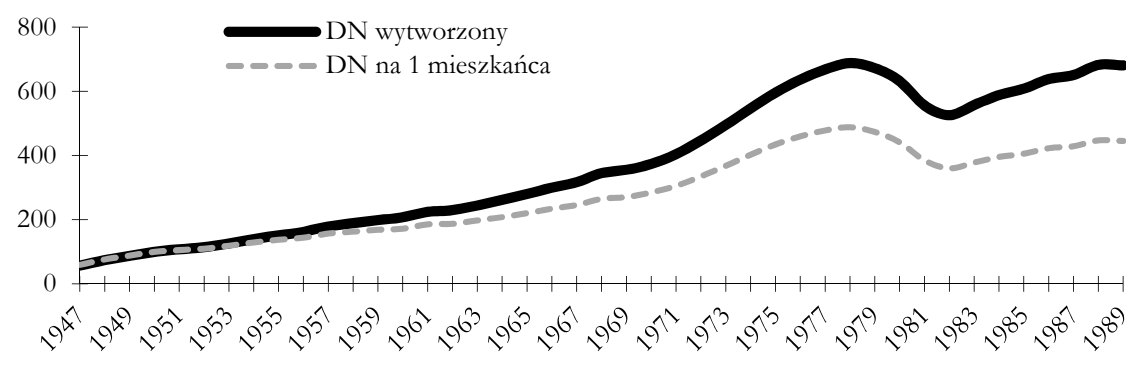

Źródło: [Podstawowe..., 1991, s. 4-5]. 
W połowie 1980 roku pojawiły się zwiastuny kolejnego przesilenia politycznego w PRL, tym razem w formie natychmiastowej i zdecydowanej reakcji robotników dużych zakładów przemysłowych na urzędową podwyżkę cen mięsa. Władze, przeciwne rozwiązaniom siłowym, 31 sierpnia zgodziły się na podpisanie porozumień ze strajkującymi. Efektem porozumień było uznanie niezależnych związków zawodowych, które zorganizowały się we wrześniu 1980 roku pod nazwą Niezależnego Samorządnego Związku Zawodowego „Solidarność”. Dalszy przebieg wydarzeń, z których decydujące było wprowadzenie w 1981 roku stanu wojennego, wskazywał, że elity komunistyczne kurczowo trzymały się władzy i broniły skompromitowanego systemu ekonomicznego. W rezultacie przez kilka kolejnych lat trwał, zapoczątkowany w 1979 roku, spadek dochodu narodowego, a w całej dekadzie lat osiemdziesiątych jego średnioroczny wzrost wyniósł zaledwie 0,5\%. Według obliczeń Witolda M. Orłowskiego, w latach 1950-1989 przeciętny roczny wzrost PKB wyniósł tylko 2,2\% [Orłowski, 2010, s. 54]. W następstwie do 1989 roku udział Polski w globalnym PKB obniżył się do 0,81\%. Nastapił jej spadek na liście rozwiniętych gospodarek z 16. miejsca w 1978 roku na 20. miejsce w 1989 roku. Zgodnie z obliczeniami Wójtowicza, PKB na mieszkańca z 1978 roku zmniejszył się o 7\% i w 1989 roku wyniósł 7730 dol. [Wójtowicz, 2006, s. 203; Rocznik Statystyczny..., 1990, s. 120].

\section{Trzecia Rzeczpospolita. Dynamiczny wzrost w warunkach restrukturyzacji gospodarki i dyferencjacji społecznej}

Komunistyczne władze Polski, zdesperowane klęską ekonomiczna, przystapiły do rozmów z opozycją zgrupowaną wokół zdelegalizowanego NSZZ „Solidarność”. Obrady Okragłego Stołu umożliwiły przeprowadzenie w czerwcu 1989 roku częściowo wolnych wyborów do Sejmu i Senatu. Klęska wyborcza komunistów otworzyła w powojennej Polsce drogę do powstania pierwszego demokratycznego rządu, na którego czele staną Tadeusz Mazowiecki. Sprawy gospodarcze znalazły się w kompetencji wicepremiera i ministra finansów Leszka Balcerowicza.

Początek wdrażania zmian systemowych w Polsce, zainicjowany „planem Balcerowicza”, przyniósł krótkotrwała, ale dotkliwa gospodarczo i społecznie recesję transformacyjna. W 1990 roku PKB spadł o 8\%, a w 1991 roku o dalsze 7\%, głównie w wyniku dramatycznego regresu produkcji materialnej. Zadecydował o tym: spadek popytu wewnętrznego, utrata rynków rozpadającego się bloku radzieckiego i narastająca konkurencja ze strony firm zachodnich. Jednak już w latach 1992-1994 średnioroczny przyrost PKB wyniósł 3,8\%. Okres szczególnie wysokiej koniunktury wystapił w latach 1995-1997 , z przeciętnym przyrostem PKB na poziomie 6,6\%. Na przełomie wieków stopniowo wyczerpywały się proste rezerwy wzrostu gospodarczego i komplikowały stosunki zewnętrzne. Jednocześnie dawały o sobie znać zaniechania w reformowaniu gospodarki. W konsekwencji w latach 1998-2000 przeciętny roczny przyrost PKB obniżył się do 4,4\%, a w latach 2001-2002 nawet do 1,3\%. Rosnący popyt wewnętrzny i pozytywne impulsy zewnętrzne, zwłaszcza związane z wejściem Polski do Unii Europejskiej, sprawiły, że w latach 2003-2007 średnioroczny przyrost PKB sięgnął 5,1\%. Od 
2008 do 2014 roku, w związku z przedłużającym się światowym kryzysem finansowym i zwolnieniem reform strukturalnych, dynamika produktu krajowego obniżyła się do 2,3\% [Poland..., 2001, s. 251; Real GDP, 2016].

WYKRES 3.

Dynamika PKB w Polsce i w Unii Europejskiej w latach 1990-2014

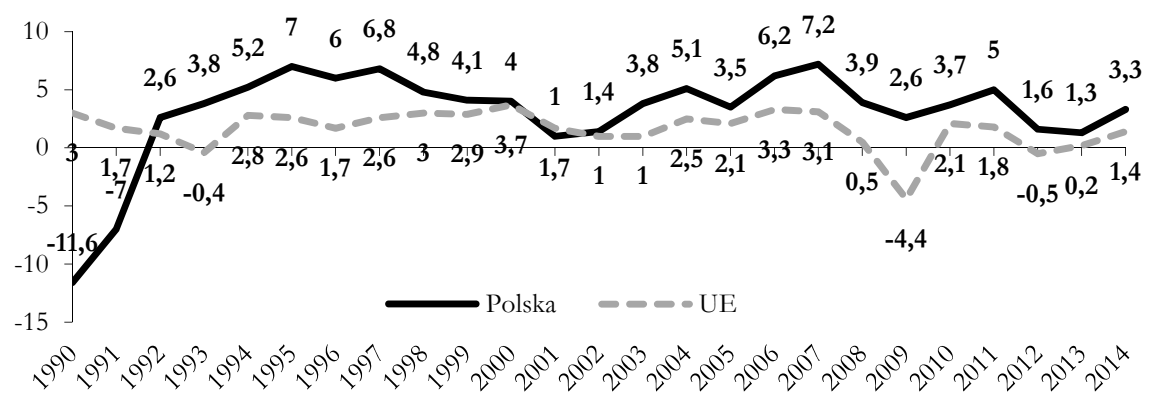

Źródło:[Poland..., 2001, s. 251; Real GDP, 2016].

Poziom PKB z 1990 roku w połowie lat dziewięćdziesiątych został przekroczony o ponad 11\%, zaś w 2008 roku był już dwukrotnie wyższy. Do 2013 roku analizowany wskaźnik powiększył się o blisko $130 \%$. Relatywnie wysoki i równomierny wzrost gospodarczy Polski po 1989 roku zaowocował szybkim przyrostem PKB na mieszkańca. W 2004 roku był on o ponad 120\% wyższy od poziomu uzyskanego w ostatnim roku rządów komunistycznych, zaś w latach 2005-2014 wzrósł o dalsze 62\%. Według danych Banku Światowego, PKB na mieszkańca Polski (liczony w dolarach międzynarodowych z 2011 roku) wzrósł z 10140 dol. w 1990 roku do 23976 dol. w 2014 roku, czyli o 136\% [Rapacki, 2006, s. 6; Rocznik. Statystyczny Rzecsypospolitej Polskiej..., 2009, s. 54; Polska..., 2014, s. 95; Polska..., 2015, s. 113; http://databank.worldbank.org/data/ reports.aspx?source $=$ world-development-indicators\#s_g, data wejścia: 14.04.2016].

Przemiany ustrojowe dogłębnie przeobraziły polska gospodarkę, tworząc solidne podstawy systemu rynkowego. Od 1992 roku pozytywnym tendencjom w sferze koniunktury gospodarczej towarzyszyły w różnym stopniu zaawansowane procesy restrukturyzacyjne. Pod wpływem ekspansji sektora prywatnego odsetek w nim zatrudnionych zwiększył się z 48 w 1990 roku do 71 w 2004 roku i 77 w 2014 roku [Rocznik Statystyczny Rzecryypospolitej Polskiej..., 1999, s. 129; Rocznike Statystyczny Rzecrypospolitej Polskiej..., 2005, s. 234; Rocznik. Statystyczny Rzecaypospolitej Polskiej..., 2015, s. 241]. W wyniku prywatyzacji został złamany monopol wielkich organizacji państwowych, chluby gospodarki centralnie kierowanej. Tylko w latach 2005-2014 powstało ponad 0,5 mln głównie drobnych przedsiębiorstw prywatnych, a ich ogólna liczba przekroczyła $5 \mathrm{mln}$ [Rocznik Statystyczny Rzeczypospolitej Polskiej..., 2015, s. 731]. Równocześnie zmodernizowano lub stworzono od podstaw firmy reprezentujące zagraniczny kapitał, wykorzystujące nowoczesne technologie i metody zarządzania. 
Depresja transformacyjna, a w następstwie zmienny wzrost gospodarczy wywołały trudne zjawiska społeczne. Ich szczególnym przejawem był silny spadek zatrudnienia, który w latach 1990-1993 objął ponad 2,6 mln osób [Rajkiewicz, 1997, s. 49]. Z całą siłą ujawniły się czynniki generowane przez zmiany systemowe związane z restrukturyzacja gospodarki i tworzeniem rynku pracy. Typowym zjawiskiem stały się tzw. zwolnienia grupowe w upadających uspołecznionych zakładach przemysłowych oraz w likwidowanych państwowych gospodarstwach rolnych. W okresie gospodarki centralnie kierowanej było powszechne zjawisko bezrobocia ukrytego, które dynamicznie przekształcało się w bezrobocie jawne.

Silny spadek zatrudnienia, a następnie jego niska dynamika wzrostowa sprawiły, że szczególnym problemem społecznym stało się bezrobocie. Rozmiary bezrobocia w 1993 roku zbliżyły się do 2,9 mln osób, a stopa bezrobocia wyniosła 16,4\%. Najwyższy poziom bezrobocia (3,2 mln osób) notowano w latach 2002-2003. Po wejściu Polski do Unii Europejskiej, pod wpływem ożywienia koniunktury gospodarczej oraz rosnących możliwości podejmowania pracy przez Polaków za granica, bezrobocie zaczęło szybko spadać. W 2014 roku zarejestrowanych było 1,8 mln bezrobotnych, a stopa bezrobocia stanowiła 11,5\% [Polska..., 2008..., s. 32; Informacja..., 2015, s. 7].

Załamaniu gospodarczemu w latach 1990-1991 i spadkowi zatrudnienia towarzyszyło długotrwałe obniżenie dochodów z pracy oraz emerytur i rent. Od 1994 roku stopniowo zaczęły rosnąć płace oraz świadczenia społeczne, realny poziom emerytur i rent z 1989 roku przekroczono w 1997 roku, zaś płac dopiero w 2004 roku. W 2013 roku płace realne były już o 28\%, a renty i emerytury o 55\% wyższe w porównaniu z 1989 rokiem [Rajkiewicz, 1997, s. 85; Golinowska, 2010, s. 9; Polska 1989-2014..., 2014, s. 30-33].

Dochody ludności, które uległy gwałtownemu załamaniu na początku transformacji, dopiero w latach 1996-2003 wykazywały słabą, a jednocześnie zmienną tendencję wzrostowa, od około 7\% w 1997 roku do 0,3\% w 2002 roku. Generalnie, dochody gospodarstw domowych rosły w tempie wolniejszym od wzrostu całej gospodarki. W latach 1996-2000 wyniosły 3,4\%, podczas gdy PKB podniósł się o 5,5\%, natomiast w latach 2001-2004 odpowiednio o: 1,3\% i 2,9\% [Polska 2006..., 2006, s. 152].

Poprawa sytuacji ekonomicznej polskiego społeczeństwa od końca dekady lat dziewięćdziesiąych wiązała się ze zjawiskiem silnego zróżnicowania społecznego. Syntetyczną miara narastających nierówności w osiaganych dochodach było kształtowanie się współczynnika Giniego, który między 1992 a 2004 rokiem podniósł się z 26,7 do 35,4 [http://data.worldbank.org/indicator/SI.POV.GINI, data wejścia: 14.04.2016]. Od momentu wejścia Polski do Unii Europejskiej następowało osłabienie dyferencjacji dochodowej społeczeństwa, a współczynnik Giniego zmniejszył się do 30,8 w 2014 roku i prawie wyrównał ze średnim dla 28 państw Unii Europejskiej $(31,0)$ [Dochody..., 2015]. Mimo tych korzystnych zmian, ogółem w latach 1990-2014, w warunkach znacznego wzrostu gospodarczego i podniesienia ogólnego poziomu cywilizacyjnego pogłębiło się zróżnicowanie społeczeństwa polskiego pod względem ekonomicznym.

Przechodząc do porównań międzynarodowych, należy zauważyć, że Polska, w wyniku radykalnych reform odczuła pozytywne tendencje w gospodarce już w 1992 roku. Inne państwa regionu, które podjęły transformację, później odczuły zmiany, a mianowicie 
Czechy i Węgry w 1994 roku, a Litwa w 1995 roku. Poziom PKB z 1989 roku Polska przekroczyła w 1995 roku, gdy Czechy i Węgry w 2000 roku, a Litwa dopiero po 2004 roku [Rapacki, Próchniak, 2006, s. 7; Rocznik Statystyczny Rzecrypospolitej Polskiej..., 2009, s. 54; Polska ..., 2014, s. 95]. Do 2013 roku PKB Polski zwiększył się o blisko 130\%, zaś Czech o 47\%, a Niemiec o 40\% [Raport..., 2014, s. 95]. Wprawdzie były to państwa o wyższym poziomie gospodarczym, w których trudniej utrzymać wysoką dynamikę gospodarki, to ta argumentacja nie mogła podważyć pozycji Polski jako lidera przemian gospodarczych w regionie.

Wzrost gospodarczy Polski od 1992 roku był także widoczny na tle świata. Jej udział w produkcji światowej (liczony wartością PKB według cen bieżących w dolarach amerykańskich) zwiększył się z 0,29\% w 1990 roku do 0,70\% w 2014 roku. Polska gospodarka awansowała odpowiednio z 34. miejsca na 23. wśród państw świata [GDP at market prices].

Na podkreślenie zasługuje fakt, że dynamika PKB w Polsce, poza 2001 rokiem, była zawsze wyższa od średniej państw, które tworzyły Unię Europejska. W połowie ostatniej dekady XX wieku oraz na przełomie pierwszej i drugiej dekady XXI wieku rozbudziło to nadzieje na doganianie krajów bardziej rozwiniętych od Polski. Początek drugiej dekady XXI wieku okazał się mniej optymistyczny dla polskiej gospodarki, co ostudziło nadzieję na szybką konwergencję. Mimo to, Polska była jedynym krajem Europy Środkowej i Wschodniej, któremu udało się zredukować rozpiętość w poziomie rozwoju, mierzonym PKB per capita według parytetu siły nabywczej, w stosunku do 15 starych państw Unii Europejskiej. W 1989 roku wskaźnik ten wynosił 38\% przeciętnego poziomu europejskiego, natomiast w 2005 roku - 46\%. Liczony w stosunku do 28 państw Unii Europejskiej wzrósł z 49\% w 2004 roku do 68\% w 2014 roku, lecz dało to Polsce dopiero 23. lokatę przed: Bułgarią, Rumunia, Chorwacja, Łotwa, a razem z Wegrami [Rapacki, 2006, s. 6; http://ec.europa.eu/eurostat/web/purchasing-power-parities/data/main-tables, data wejścia: 14.04.2016].

\section{Podsumowanie}

Analiza wzrostu gospodarczego Polski po 1918 roku wskazuje, że zarówno w Drugiej Rzeczypospolitej, PRL-u, jak i w Trzeciej Rzeczypospolitej, mimo stosunkowo długich okresów dobrej koniunktury, nie udało się rozwiązać podstawowych problemów rozwoju. W latach międzywojennych nie przezwyciężono silnego zróżnicowania regionalnego, artykułowanego w pojęciach „Polski A” i „Polski B”. Ziemie na wschód od Wisły zdecydowanie ustępowały regionom zachodnim pod względem potencjału gospodarczego i poziomu dobrobytu. Na skutek niskiego poziomu industrializacji utrzymywało się wielomilionowe przeludnienie agrarne, ograniczające rozwój rynku wewnętrznego i stanowiące podstawę ubóstwa podstawowej części społeczeństwa.

Trwający do 1978 roku wzrost gospodarczy PRL, oparty na forsownej industrializacji i wykorzystujący konsekwencje zmiany granic politycznych, wprawdzie rozwiązał szereg problemów odziedziczonych po Drugiej Rzeczypospolitej, ale stworzył nowe. Wynikały one z niedostosowania struktury gospodarczej kraju do potrzeby podnoszenia 
stopy życiowej ludności. Permanentne niedostatki artykułów konsumpcyjnych, niski poziom usług i zaniedbania w sferze infrastruktury były powodem kilkukrotnych wystapień społecznych przeciwko władzy, które nie były skore do zasadniczych zmian nieefektywnego systemu ekonomicznego.

W 1989 roku jego krach doprowadził do ukształtowania pierwszego po wojnie rządu demokratycznego. Reformy ekonomiczne podjęte przez nowe władze, skierowane w stronę tworzenia gospodarki rynkowej, początkowo doprowadziły do depresji transformacyjnej, aby od 1992 roku wprowadzić gospodarkę na ścieżkę wzrostu. W pierwszych latach skorzystała z niej stosunkowa nieliczna grupa społeczna, która była w stanie dostosować się do nowych warunków ekonomicznych. Generalnie, na skutek wysokiego bezrobocia i spadku dochodów, narastało ubóstwo i zjawisko wykluczenia społecznego. Zróżnicowanie społeczne szczególnie było widoczne na początku XXI wieku. Jego złagodzenie przyniosło wejście Polski do Unii Europejskiej, które podtrzymało długookresowy wzrost gospodarczy.

\section{Literatura}

Bartosik Z., 1988, Strukturalne problemy przemystu polskiego, Zakład Narodowy im. Ossolińskich - Wydawnictwo, Wrocław.

Błahut K.J., 1984, Zmiany struktury produkcii przemystowej i eksportu w Polsce w latach 19601978, Wydawnictwo PW, Wrocław.

Bożyk B., 1983, Marzenia i rzeçywistość, czyli anatomia polskiego kryzysu, Państwowy Instytut Wydawniczy, Warszawa.

Dochody i warunki życia ludności Polski (raport z badań EU-SILC 2014), 2015, GUS, Warszawa.

GDP at market prices, http://data.worldbank.org/indicator/NY.GDP.MKTP.CD/ countries?display=default (data wejścia: 20.05.2016).

Golinowska S., 2010, Polityka wobec ubóstwa i wykluczenia społecænego w minionym dwudziestoleciu, „Polityka Społeczna”, nr 9.

Gołębiowski J., 1985, Sektor państwowy w gospodarce Polski międzywojennej, Państwowe Wydawnictwo Naukowe, Warszawa, Kraków.

Historia Polski w liczbach. Gospodarka, 2006, GUS, Warszawa.

http://data.worldbank.org/indicator/SI.POV.GINI (data wejścia: 14.04.2016).

http:/ / databank.worldbank.org/data/reports.aspx?source=world-development-indicators\#s_g (data wejścia: 14.04.2016).

http:/ / ec.europa.eu/eurostat/web/purchasing-power-parities/data/main-tables (data wejścia: 14.04.2016).

Informacja o sytuacji społeczno-gospodarczej kraju w 2014 roku, 2015, GUS, Warszawa.

IV Zjazd Polskiej Zjednoczonej Partii Robotniczej, 15-20 czerwca 1964 roku. Podstawowe materiaty $i$ dokumenty, 1964, Książka i Wiedza, Warszawa.

Jaroszewicz P., 1991, Przerywam milczenie: 1939-1989, „Fakt”, Warszawa.

Jędrychowski S., 1982, Zadtużenie Polski w krajach kapitalistycznych, Książka i Wiedza, Warszawa. 
Kaliński J., 1987, Polityka gospodarcza Polski w latach 1948-1956, Książka i Wiedza, Warszawa.

Kaliński J., 1995, Gospodarka Polski w latach 1944-1989. Przemiany strukturalne, Polskie Wydawnictwo Ekonomiczne, Warszawa.

Kuziński S., 1954, Proporcje miedsy przemystem a rolnictwem w okresie przejscionym od kapitalizmu do socjalizmu, „Ekonomista”, $\mathrm{nr} 1$.

Landau Z., Tomaszewski J., 1971, Gospodarka Polski miedsynojennej, t. II, Ksiazżka i Wiedza, Warszawa.

Landau Z., Tomaszewski J., 1989, Gospodarka Polski miedsynojennej, t. IV, Ksiażka i Wiedza, Warszawa.

Landau Z., Tomaszewski J., 1999, Zarys historii gospodarcæej Polski 1918-1939, Książka i Wiedza, Warszawa.

Lijewski T., 1978, Uprzemystowienie Polski 1945-1975. Prz̧emiany strukturalne ipržestrzenne, Państwowe Wydawnictwo Naukowe, Warszawa.

Luszniewicz J., 2010, Druga Rzeczpospolita. Wrorost podporz̨adkowany integracji i modernizacji gospodarki, [w:] Polskie osiagniecia gospodarcze. Perspektywa historyczna, J. Kaliński (red.), Wydawnictwa Akademickie i Profesjonalne, Warszawa.

Małecka T., 1989, Præemyst. Warunki rozwoju, [w:] Problemy gospodarcze Drugiej Ržečypospolitej, 1989, Polskie Wydawnictwo Ekonomiczne, Warszawa.

Minc H., 1950, Széscioletni Plan Rozpoju Gospodarczego i Budowy Podstaw Socjalizmu w Polsce. Referat wygtoszony na V Plenum Komitetu Centralnego dnia 15 lipca 1950 roku, „Nowe Drogi", nr 4.

Orłowski W.M, 2010, W pogoni za straconym czasem. W zrost gospodarçy w Europie Środkowo-W schodniej 1950-2030, Polskie Wydawnictwo Ekonomiczne, Warszawa.

Podstawowe dane statystyczne o Polsce 1946-1990, 1991, GUS, Warszawa.

Poland into the New Millennium, 2001, G. Blazyca, R. Rapacki (eds.), EE, Cheltenham.

Polska 1989-2014, 2014, GUS, Warszawa.

Polska 2006. Raport o stanie gospodarki, 2006, Ministerstwo Gospodarki, Warszawa.

Polska 2008. Raport o rynku pracy oraz, Zabezpieczeniu spotecznym, 2008, Ministerstwo Pracy i Opieki Społecznej, Warszawa.

Polska 2014. Raport o stanie gospodarki, 2014, Ministerstwo Gospodarki, Warszawa.

Polska 2015. Raport o stanie gospodarki, 2015, Ministerstwo Gospodarki, Warszawa.

Polska w latach 1970-1980, 1981, GUS, Warszawa.

Polska w liczbach 2015, 2015, GUS, Warszawa.

Rajkiewicz A., 1997, Dochody i wydatki ludności. Minimum socjalne, [w:] Społeczeństwo polskie w latach 1989-1995/96. Zagadnienia polityki spotecznej, A. Rajkiewicz (red.), Wydawnictwo Uniwersytetu Warszawskiego, Warszawa.

Rajkiewicz A., 1997, Zatrudnienie i rynek pracy, [w:] Spoteczeństwo polskie w latach 19891995/96. Zagadnienia polityki spolecznej, A. Rajkiewicz (red.), Wydawnictwo Uniwersytetu Warszawskiego, Warszawa.

Rapacki R., 2006, W zrost gospodarçy $i$ zmiany poziomu dochodów w krajach postsocjalistycznych w latach 1990-2005 - obraz empiryczny, [w:] Konferencja naukowa pt.: Ścieżki wžrostu gospodarczego w krajach postsocjalistycznych w latach 1950-2005: konwergencja cay dywergencja?, Oficyna Wydawnicza Szkoły Głównej Handlowej, Warszawa. 
Rapacki R., Próchniak M., 2006, Rachunek wrostu gospodarczego w krajach postsocjalistycznych w latach 1993-2003, [w:] Konferencja naukowa pt.: Ścieżki wrovostu gospodarczego w kerajach postsocjalistycznych w latach 1950-2005: konwergencja czy dywergencja?, Oficyna Wydawnicza Szkoły Głównej Handlowej, Warszawa.

Raport o stanie gospodarki, 2014, Ministerstwo Gospodarki, Warszawa.

Real GDP growth rate, http:/ /ec.europa.eu/eurostat/data/database (data wejścia: 14.04.2016).

Rocznike Statystyczny 1971, 1971, GUS, Warszawa.

Rocznike Statystyczny 1976, 1976, GUS, Warszawa.

Rocznike Statystyczny 1983, 1983, GUS, Warszawa.

Rocznik Statystyczny 1990, 1990, GUS, Warszawa.

Rocznik Statystyczny Rzeczypospolitej Polskiej 1999, 1999, GUS, Warszawa.

Rocznik Statystyczny Rzeczypospolitej Polskiej 2005, 2005, GUS, Warszawa.

Rocznik Statystyczny Rzeczypospolitej Polskiej 2009, 2009, GUS, Warszawa.

Rocznik Statystyczny Rzeczypospolitej Polskiej 2015, 2015, GUS, Warszawa.

Szyr E., 1959, Niektóre problemy rozwoju gospodarki narodowej w latach 1959-1965, Książka i Wiedza, Warszawa.

Tomaszewski J., Landau Z., 2005, Polska w Europie i swiecie 1918-1939, TRIO, Warszawa.

Wójtowicz G., 2006, Trendy i ewolucja. Drieje gospodarcze żiem polskich, Twiger, Warszawa. 